Portland State University

PDXScholar

TREC Final Reports

Transportation Research and Education Center

(TREC)

$11-2008$

Road Ecology Course and Seminar Series

Mark D. Sytsma

Portland State University, sytsmam@pdx.edu

Follow this and additional works at: https://pdxscholar.library.pdx.edu/trec_reports

Part of the Transportation Commons, Urban Studies Commons, and the Urban Studies and Planning Commons

Let us know how access to this document benefits you.

Recommended Citation

Mark Sytsma. Road Ecology Course and Seminar Series. OTREC-ED-08-02. Portland, OR: Transportation Research and Education Center (TREC), 2008. https://doi.org/10.15760/trec.95

This Report is brought to you for free and open access. It has been accepted for inclusion in TREC Final Reports by an authorized administrator of PDXScholar. Please contact us if we can make this document more accessible: pdxscholar@pdx.edu. 


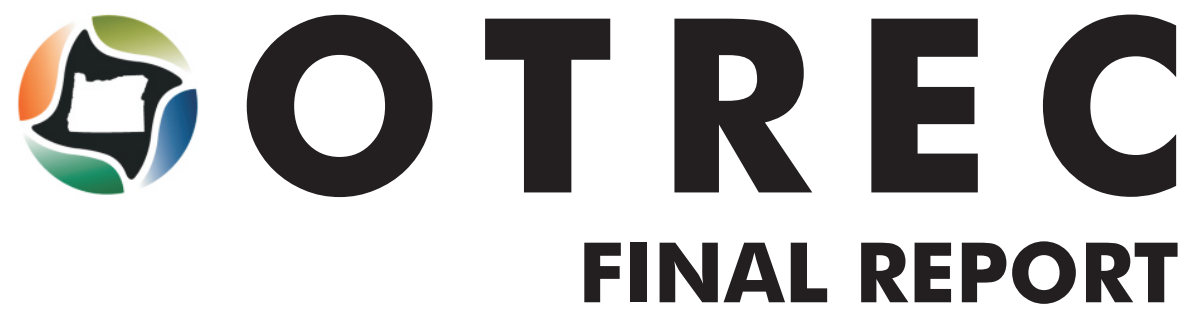

\section{Road Ecology Course and Seminar Series}

\author{
OTREC-ED-08-02 \\ November 2008
}
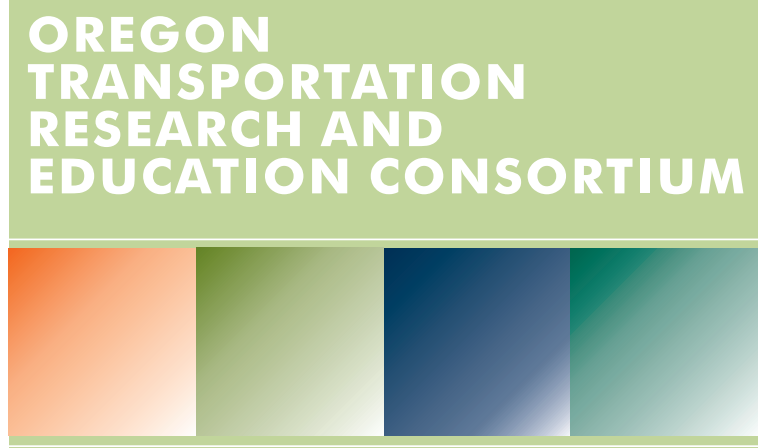


\title{
ROAD ECOLOGY COURSE AND SEMINAR SERIES
}

\author{
Final Report \\ OTREC-ED-08-02 \\ by \\ Mark Sytsma \\ Portland State University
}

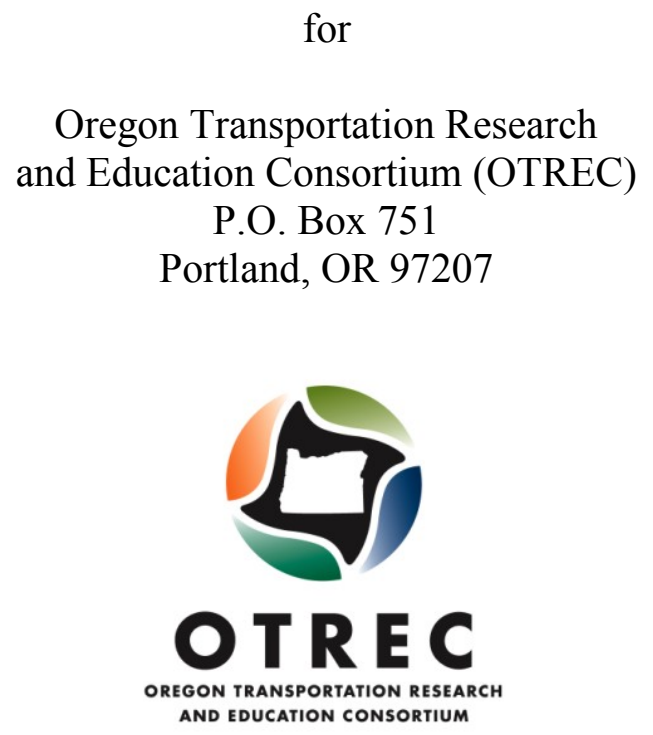

November 2008 



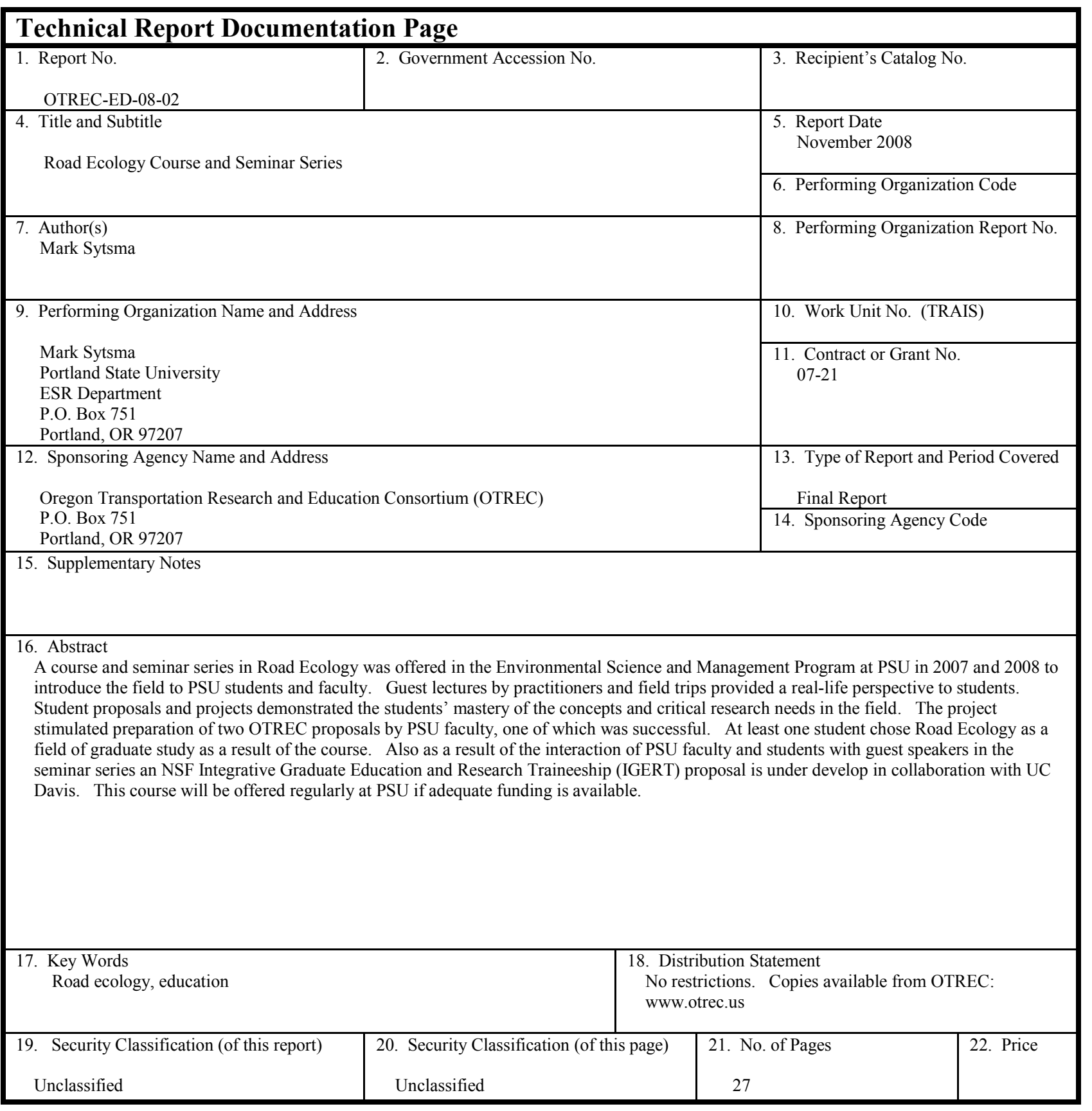




\section{ACKNOWLEDGEMENTS}

We would like to thank the guest speakers who collaborated on this project for over two years. Without their enthusiastic support for the education of our students on various aspects of road ecology, this project could not have been successful.

\section{DISCLAIMER}

The contents of this report reflect the views of the authors, who are solely responsible for the facts and the accuracy of the material and information presented herein. This document is disseminated under the sponsorship of the U.S. Department of Transportation University Transportation Centers Program and the Oregon Transportation Research and Education Consortium at Portland State University (OTREC) in the interest of information exchange. The U.S. Government and OTREC assume no liability for the contents or use thereof. The contents do not necessarily reflect the official views of the U.S. Government or OTREC. This report does not constitute a standard, specification, or regulation. 


\section{TABLE OF CONTENTS}

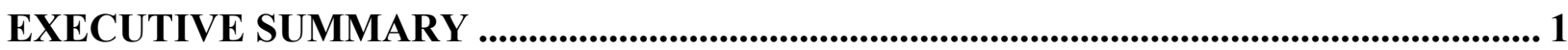

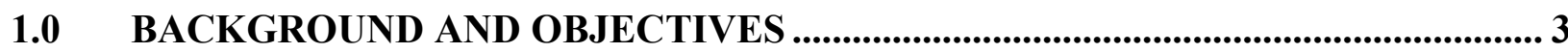

2.0 PROJECT DESCRIPTION ……................................................................................. 5

3.0 OUTCOME AND RESULTS....................................................................................... 7

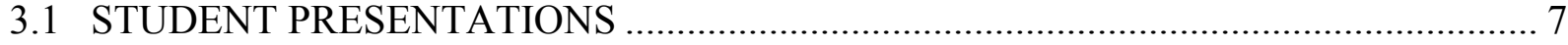

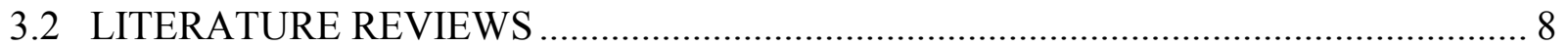

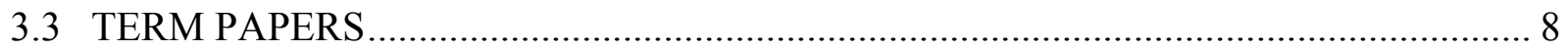

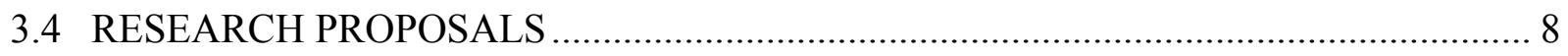

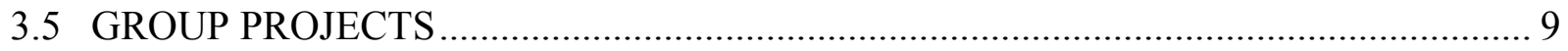

3.6 STUDENT AND GUEST SPEAKER FEEDBACK ……………….......................... 10

4.0 FURTHER ACTIVITIES ............................................................................................. 11

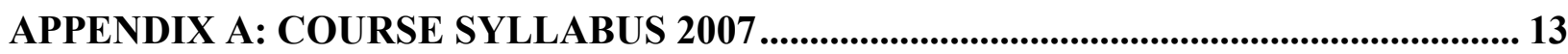

APPENDIX B: COURSE SYLLABUS 2008 ................................................................................. 19

APPENDIX C: SEMINAR SERIES....................................................................................... 25

APPENDIX D: FIELD TRIP PHOTOS ..................................................................................... 27

APPENDIX E: EVALUATION FORM FOR STUDENT PRESENTATIONS .................... 31

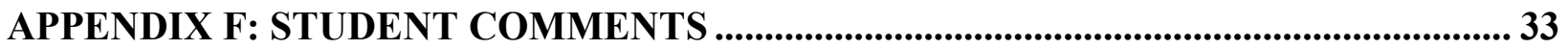




\section{EXECUTIVE SUMMARY}

A Road Ecology course was offered to upper-division undergraduate students and graduate students at Portland State University (PSU) in 2007 and 2008. The course was well-attended and included students from diverse backgrounds and majors. Guest speakers and field trips provided the students with real-world examples of the environmental impacts of roads and the techniques available for mitigating those impacts. In addition, a seminar series focused on environmental impacts of roads and their mitigation.

A primary objective of the project was to introduce the field of Road Ecology to PSU students and faculty. The project resulted in two new Road Ecology proposals submitted to OTREC, one of which was funded. In addition, one student chose Road Ecology as an area of research as a result of the project. An additional benefit was increased recognition among agency personnel of PSU's interest and capabilities in Road Ecology research. 


\subsection{BACKGROUND AND OBJECTIVES}

The American road network is a major economic investment that is a significant organizing force for human activity. The road system has profoundly altered ecological processes and, as a result, it is also an important organizing force for ecosystems. Understanding the ecological consequences of road system design and use is critical to effective engineering and management that may minimize impacts.

Environmental stewardship and workforce training are important components of the U.S. Department of Transportation's Strategic Plan, and the National Highway Research and Technology Partnership's Highway Research and Technology: The Need for Greater Investment report recognizes the importance of environmental issues to infrastructure and operation of the transportation system.

The PSU Environmental Science and Resources Program offers a range of courses that lead to two bachelor's degrees, two master's degrees and a doctoral degree. The department's coursework and research is interdisciplinary and wide-ranging. The program has major research strength in freshwater and marine ecology and air quality. The program houses the Urban Ecological Research Consortium that focuses on ecological impacts of urbanization, including traffic and transportation issues, and the Center for Lakes and Reservoirs/Aquatic Bioinvasion Research and Policy Institute, which addresses water quality issues broadly and transport of invasive species by various vectors, particularly vehicles and ships.

This project was designed to:

- Offer a Road Ecology course to PSU students, exposing them to the major issues and fields of study relating to the environmental impacts of roads;

- Provide a series of seminars to introduce a broad spectrum of PSU students to the Road Ecology field;

- Stimulate interest in Road Ecology research among PSU students and faculty; and

- Facilitate collaboration among PSU faculty and students with agencies that regulate and mitigate environmental impacts of roads. 


\subsection{PROJECT DESCRIPTION}

The Environmental Science Program offered a Road Ecology course during Spring Quarter 2007. The course was not included in the course offerings catalog for the quarter because the course was developed too late. Still, it attracted seven undergraduate and six graduate students. In Spring Quarter 2008, it had 11 undergraduate and two graduate students. Speakers from the U.S. Forest Service, the Oregon and Washington transportation departments, the Oregon Department of Fish and Wildlife, the city of Wilsonville, the Federal Highway Administration and elsewhere provided guest lectures. All guest lecturers in 2007, who were asked to return during the Spring 2008 semester, agreed with enthusiasm and updated the work they presented in 2007. Additionally, the course expanded the lecturers to include guests from the University of California-Davis Road Ecology Center, an air quality researcher from PSU, and the city of Portland Green Streets Program.

The Road Ecology course was a reading and discussion course for upper-division undergraduate and graduate students; it focused on environmental impacts of roads and how they are mitigated. Guest lecturers and field trips brought real-world perspectives to the class and helped students understand current problems and research needs. Students selected topics for peer-reviewed literature, term papers (undergraduate students), research proposals (graduate students), and student-led group lectures.

In Spring 2008, the course also included group projects that covered a wide range of topics, but were all designed to have an end product that could be used by researchers, managers or the public. These projects fostered a relationship with external groups including the city of Wilsonville and ODOT, and provided the students with a practical application of the topics. The class allowed students to better understand the major environmental issues associated with road system construction, maintenance and operation. The course syllabus, field trip photos, and guest lecturer title slides are in this report's Appendix. Guest speaker presentations and course material are available on the course Web site (2007: www.web.pdx.edu/ $\sim$ sytsmam/roadecology and 2008: https://bb.pdx.edu/webct/urw/lc5122011.tp0/cobaltMainFrame.dowebct).

Four departmental seminars on Road Ecology were presented during Spring Quarter 2007. Speakers discussed OTREC's history and purpose, wildlife impacts, logging road impacts on water quality and roadside vegetation management. 


\subsection{OUTCOME AND RESULTS}

PSU students from the Environmental Sciences and Resources (ESR), Urban Studies and Planning, and Geology programs registered for the Spring 2007 term. Spring 2008 included students from Urban Studies and Planning, Environmental Sciences, English, Architecture, Art, Graphic Design, Biology, Environmental Sciences and Management. Seminars were attended by 40 undergraduate and graduate students with a broad range of interests and majors.

The course was a catalyst for student and faculty participation in developing solutions to transportation-related environmental issues and instigated proposals for submission to OTREC. Specifically,

- An incoming graduate student of Dr. Catherine deRivera (ESR) collaborated with the city of Wilsonville to evaluate the efficacy of wildlife passage structures incorporated into the Boeckman Road extension through a wetland. This project was funded by OTREC in 2008. The city of Wilsonville is providing the required project match.This project was a direct outcome of a guest lecture and field trip in the Road Ecology course.

- Dr. Linda George (ESR) developed an OTREC proposal titled, "Assessing the potential for biological mitigation strategies of mobile sources of air toxins" in collaboration with Dr. Vivek Shandas (PSU-CUPA), Todd Rosenstiel (PSU-Biology), and John Lambrinos (OSU-Horticulture). This project resulted from a guest lecture by Gail Achterman, chair of the Oregon Transportation Commission and director of Oregon State University's Institute for Natural Resources. She mentioned the project as an opportunity for interdisciplinary cooperation focused on air quality impacts of highways.

- Dr. Alison Berry, from UC-Davis, was a guest lecturer in 2008. As a result of her visit, collaborative proposals are planned related to environmental impacts of roads. Specifically, we discussed an NSF Integrated Graduate Education and Research Training (IGERT) proposal that would combine expertise at PSU and UC-Davis in road ecology.

\subsection{STUDENT PRESENTATIONS}

In 2007, students organized into groups and prepared lectures on 1) how roads impact wildlife, 2) impervious road surfaces and water quality, 3) how roads contribute to the spread of invasive species, and 4) the effects of roads on air quality. Student groups prepared PowerPoint presentations, provided advance reading material and facilitated the discussion. Students in the audience were asked to evaluate their peers as part of their participation grade. The evaluation form is provided in the Appendix.

In 2008, students prepared individual presentations on key research and ideas on a theme selected from chapters in their textbook Road Ecology (ed. Forman et al.). Individuals gave an 
overview of the topic and then supported the main concepts with examples from primary literature sources. Graduate students also were asked to lead the class through a discussion of a scientific paper relevant to their topic.

\subsection{LITERATURE REVIEWS}

Students critically reviewed three (undergraduate) or five (graduate) road ecology-related papers from peer-reviewed journals. Each review included the following elements:

- $\quad$ The complete reference (this should be primary, peer-reviewed literature);

- A one- or two-sentence summary of the paper;

- $\quad$ A deeper, more extensive outline of the paper's main points, including assumptions made, arguments presented, data analyzed and conclusions drawn;

- $\quad$ Limitations of the results or new ideas stimulated by the paper; and

- Their opinion of the quality of the ideas and the paper's potential impact.

\subsection{TERM PAPERS}

Selected titles of term papers submitted by undergraduates in the 2007 and 2008 Road Ecology courses:

- The effect of artificial and natural barriers on the movement of small mammals in Banff National Park, Canada.

- Road impacts on habitat fragmentation and mitigation methods.

- Pavement, water quality, and water quantity: Can permeable pavement mitigate the effects of roads on the environment?

- Why do roads facilitate invasive species? Case studies of Himalayan Blackberry and Scotch Broom.

- Phytoremediation: Using planted roadsides to remove pollutants.

- Specific impacts of road chemicals on wildlife.

- Road networks and habitat fragmentation.

\subsection{RESEARCH PROPOSALS}

Selected titles of research proposals prepared by graduate students in the 2007 Road Ecology course: 
- Investigation of control techniques on invasive plant species along roadsides in Oregon.

- Effects of roads on population size and habitat use of the common kingsnake, Lampropeltis getula, in southern Oregon.

- Lichen community composition as a biomonitor of the spatial impact of a highway on a national forest.

- Immediate and long-term effectiveness of wildlife crossing structures.

- Possible facilitation of the spread of spotted knapweed (Centaurea biebersteinii) by increasing mule deer (Odocoileus hemionus) movement through the use of wildlife underpasses in Banff National Park in Alberta, Canada.

\subsection{GROUP PROJECTS}

In Spring 2008, we increased the focus on interfacing with other agencies. Group projects were specifically designed to continue or initiate collaboration with governmental and academic groups within and outside of PSU. Titles of group projects completed by small groups (2-5 people), a brief description and the name and association of their external contact are described below.

Measuring swale effectiveness: A survey of heavy metals and polynuclear aromatic hydrocarbons. Students went to three swales and sampled soils at the inflow, midpoint and exit for metals and PAH contamination. They found that the swales were effectively sequestering contaminants near the inflow, and generally saw a decrease in contaminants in the soils towards the exit. (William Fletcher and Jefferey Moore, ODOT.)

Preliminary assessment of a comparison site for the Boeckman Road Extension Project: Effectiveness of wildlife passages. Students conducted animal and roadkill surveys in a site comparable to the Boeckman Road Extension as selected by the city of Wilsonville. They found that snakes were often the most likely to be killed by traffic, and they also tracked and found signs of several other animals likely to be near the road such as deer, coyote, moles, etc. (Kerry Rappold, city of Wilsonville, and Leslie Bliss-Ketchum, PSU graduate student.)

City-dwelling animals and their interactions with roads: Helping teachers meet science standards for grade 2. Students designed a lesson plan to teach second graders about roads and wildlife. The focus was finding passage for appropriate animals in an urban setting. Students presented the lesson plan in a class as a way of working with the teacher to incorporate these concepts into the curriculum. (Mrs. Kinney, Vernon Elementary.)

Aquatic macroinvertebrates: Insects as indicators of road pollution in streams. Students surveyed a stream for macroinvertebrate insects at three locations - upstream from its intersection with a road, at the road and downstream. Insects found were classified by family 
and by tolerance to pollutants. They found an overall decrease in abundance of insects, but not a strong change in the tolerance index with respect to position near the road. (Patrick Edwards, PSU instructor.)

\subsection{STUDENT AND GUEST SPEAKER FEEDBACK}

At the end of the Spring 2008 term, the students were invited to submit comments and suggestions about the course (Appendix 4). Students expressed interest in becoming involved with the agencies that came to speak with us and appreciated the real-world application of the topics. This course also sparked an interest in the road system and increased their awareness in the complexities of designing and maintaining road networks in a sustainable fashion. In addition, it gave students the tools, contacts and background necessary to become innovative and thoughtful citizens, researchers and employees in the area of transportation.

Guest speakers also have shown enthusiasm and interest in partnering with PSU students and faculty. William Fletcher with ODOT was pleased with the students' work and hopes to continue to collaborate on a swale monitoring project. Audrey Hatch with ODFW hopes to increase contact with PSU on a GIS project identifying wildlife crossing hotspots in Oregon. Alison Berry from the UC-Davis Road Ecology Center would like to collaborate with PSU on research projects that would cover large areas of the West Coast. 


\subsection{FURTHER ACTIVITIES}

Further activities will result from interest in the subject by a junior faculty member in PSU's Environmental Science and Management Program. Dr. Catherine deRivera was successful in obtaining OTREC support for a graduate student to carry out research on wildlife passage design and effectiveness that was stimulated by this project. Dr. deRivera is willing to continue teaching the Road Ecology course and would like to develop additional research in the area if funding is available.

Secondary outcomes of the project include exposure of 26 students to the field of Road Ecology, and the engagement of PSU faculty and students with agency representatives interested in mitigating environmental impacts of roads. The students who participated have a new appreciation of the impacts of roads and how they are mitigated, and they will carry this into whatever career they pursue. At least one student chose Road Ecology as an area of graduate research. The contacts with agency personnel will permit future collaboration on other aspects of Road Ecology. 


\section{APPENDIX A: COURSE SYLLABUS 2007}

\section{Road Ecology}

Spring 2007

ESR 410 (CRN 65352) / 510 (CRN 65253)

Eppler Hall - Room 106

Tuesday and Thursday, 12:00 - 1:50

Instructor: Mark Sytsma / HSB 110 / sytsmam@pdx.edu

Office hours: by appointment

Course ftp site: web.pdx.edu/ sytsmam/road

Text: Road Ecology: Science and Solutions

This is a reading and discussion class that will focus on the environmental impacts of roads and how they can be mitigated. After taking the class, students should understand the major environmental issues associated with road system construction, maintenance and operation.

Guest lecturers will bring real-world perspectives to the class that will help students understand current problems and research needs.

\section{Schedule}

April 3. Organization of class and field trips

April 5. Dr. Robert Bertini, OTREC and environmental issues

April 10. Gail Achterman, Oregon Transportation Commission, Exec. Director Institute for Natural Resources at OSU

April 12. Discussion: Wildlife impacts, Dodd et al.; Wetlands, Houlihan et al.

April 17. Dr. Peter Singleton, USFS

April 19. Kerry Rappold, city of Wilsonville

April 24. Discussion: Impacts of highway runoff on aquatic systems (Sytsma gone)

April 26. Hal Gard, Oregon Department of Transportation

May 1. Craig Dewey, FHA, Context sensitive road design

May 3. Dr. Susan Handy, UC-Davis.

May 4. ESR Seminar - Kerry Rappold

May 8. Boeckman Creek Field Trip

May 10. Keith Mills, Oregon Department of Forestry

May 11. ESR Seminar - Keith Mills

May 15. Audry Hatch, ODFW, and Melinda Trask, ODOT

May 17. Simon Wray, ODOT

May 22. William Fletcher, ODOT - Water quality (Sytsma gone)

May 24. Discussion: TBD (Sytsma gone)

May 29. Discussion: TBD

May 31 Discussion: TBD 
June 1. ESR Seminar - Dr. Alison Berry, UC-Davis (tentative)

June 5. Student Presentations

June 7. Student Presentations

Grading: $90-100 \%=A ; 75-89 \%=B ; 60-74 \%=C ; 45-59 \%=D$

Undergraduates: $\quad$ Participation 30\%

Literature reviews (3) 15\% - Due May 29

Term Paper ( 5 pages max) 55\% - Due June 5

Graduates: $\quad$ Participation 30\%

Literature reviews (5) 25\% - Due May 29

Research Proposal (8 pages max) 45\% - Due June 5

Literature Review and Rationale

Purpose/hypotheses

Methods

Expected Benefits 


\author{
Modified from \\ "How to Read a Scientific Research Paper- a four-step guide" \\ Ann McNeal, School of Natural Science, Hampshire College, Amherst MA 01002
}

Reading research papers ("primary articles") is partly a matter of experience and skill, and partly learning the specific vocabulary of a field. If you approach it step by step, even an impossiblelooking paper can be understood.

\title{
1. Skimming.
}

Skim the paper quickly, noting basics like headings, figures and the like. A paper with good paragraph structure in the writing will allow you to read the first sentence of each paragraph (the topic sentence) and get a good outline of the main points. This takes just a few minutes. You're not trying to understand it yet, but just to get an overview.

2. Vocabulary.

Go through the paper word by word and line by line, underlining or highlighting every word and phrase you don't understand. Don't worry if there are a lot of underlinings; you're still not trying to make sense of the article.

There are several things you might do with these vocabulary and concept questions, depending upon the type of question. You can:

- Look up simple words and phrases. Often the question is simply vocabulary - what's a lateral malleolus, a christa, or the semilunar valve? A medical or biology dictionary is a good place to look for definitions. A textbook of physiology or anatomy may be a good source, because they provide more complete explanations. Your ordinary shelf dictionary is not a good source because the definitions may not be precise enough or may not reflect the way in which scientists use a word. (For example, "efficiency" has a common definition, but the physical definition is much more restricted.)

- Get an understanding from the context in which it is used. Often words that are used to describe the procedures in an experiment can be understood from the context, and may be very specific to the paper you are reading. Examples are the "lithium-free control group" in a rat experiment or the "carotene extraction procedure" in a biochemical experiment. Of course, you should be careful when deciding that you understand a word from its context because it might not mean what you think.

- Flag this phrase as belonging to one of the major concepts of the paper - it's bigger than a vocabulary question. For example, a paper about diet and cancer might refer to "risk reduction," which you would need to understand in context and in some depth.

\section{Comprehension, section by section.}

Try to deal with all the words and phrases, although a few technical terms in the Methods section might remain. Now go back and read the whole paper, section by section, for comprehension. This requires some focused time with the paper, - it may take several hours.

In the Introduction, note how the context is set. What larger question is this a part of? The author should summarize and comment on previous research, and you should distinguish 
between previous research and the actual current study. What is the hypothesis of the paper and the ways this will be tested?

In the Methods, try to get a clear picture of what was done at each step. What was actually measured? It is a good idea to make an outline and/or sketch of the procedures and instruments? Keep notes of your questions; some of them may be simply technical, but others may point to more fundamental considerations that you will use for reflection and criticism below.

In Results, look carefully at the figures and tables, as they are the heart of most papers. A scientist will often read the figures and tables before deciding whether it is worthwhile to read the rest of the article! What does it mean to "understand" a figure? You understand a figure when you can redraw it and explain it in plain English.

The Discussion contains the conclusions the author would like to draw from the data. In some papers, this section has a lot of interpretation and is very important. In any case, this is usually where the author reflects on the work and its meaning in relation to other findings and to the field in general.

4. Reflection and criticism. After you understand the article and can summarize it, then you can return to broader questions and draw your own conclusions. It is very useful to keep track of your questions as you go along, returning to see whether they have been answered. Often, the simple questions may contain the seeds of very deep thoughts about the work. For example, "Why didn't the authors dry or freeze the plant samples before analyzing them for carbohydrates? Wouldn't there be some bacterial consumption of carbohydrates in plant tissues during storage?"

Read critically: Reading a research paper must be a critical process. You should not assume that the authors are always correct. Instead, be suspicious. Critical reading involves asking appropriate questions. If the authors attempt to solve a problem, are they solving the right problem? Are there simple solutions the authors do not seem to have considered? What are the limitations of the solution (including limitations the authors might not have noticed or clearly admitted)? Are the assumptions the authors make reasonable? Is the logic of the paper clear and justifiable, given the assumptions, or is there a flaw in the reasoning? If the authors present data, did they gather the right data to substantiate their argument, and did they appear to gather it in the correct manner? Did they interpret the data in a reasonable manner? Would other data be more compelling?

Read creatively: Reading a paper critically is easy in that it is always easier to tear something down than to build it up. Reading creatively involves harder, more positive thinking. What are the good ideas in this paper? Do these ideas have other applications or extensions the authors might not have thought of? Can they be generalized further? Are there possible improvements that might make important practical differences? If you were going to start doing research from this paper, what would be the next thing you would do?

Here are some questions that may be useful in analyzing various kinds of research papers: 


\section{Introduction}

What is the overall purpose and importance of the research? How does the research fit into the context of its field? Is it, for example, attempting to settle a controversy, show the validity of a new technique or open up a new field of inquiry? Do you agree with the author's rationale for studying the question in this way?

\section{Methods}

Were the measurements appropriate for the questions the researcher was approaching? Often, researchers need to use "indicators" because they cannot measure something directly- for example, they use change in plant biomass to indicate productivity without accounting for grazing or scenescence. Were the measures in this research clearly related to the variables in which the researchers (or you) were interested? This is a place to look for how the way the authors collected the data may bias the results.

\section{Results}

What is the one major finding? Were enough of the data presented so that you feel you can judge for yourself how the experiment turned out? Did you see patterns or trends in the data that the author did not mention? Were there problems that were not addressed?

\section{Discussion}

Do you agree with the conclusions drawn from the data? Are these conclusions over-generalized or appropriately careful? Are there other factors that could have influenced, or accounted for, the results? What further experiments would you think of to continue the research or to answer remaining questions?

\section{Your Assignment}

For this class, you need to write a short, two-page (max) review of several papers of your choosing relating to some aspect of road ecology. Although this may sound like a simple assignment, I expect that it will take a significant amount of time, especially in the beginning. (Remember, I am expecting it to take several hours just to read the paper!) Keeping the above in mind as you read the paper should make the process easier.

Your one- to two-page review should include the following:

- The complete reference (this should be primary, peer-reviewed literature - if you have questions about whether a particular paper meets these criteria, talk to me);

- A one- or two-sentence summary of the paper;

- A deeper, more extensive outline of the main points of the paper, including assumptions made, arguments presented, data analyzed and conclusions drawn;

- Limitations of the results or new ideas stimulated by the paper (remember that good science typically produces more questions than answers); and

- Your opinion of the quality of the ideas and the potential impact of the paper. 


\title{
APPENDIX B: COURSE SYLLABUS 2008
}

\author{
Road Ecology \\ Spring 2008 ESR 410 (CRN 61190) / 510 (CRN 61203) \\ NH 362, Tuesday and Thursday, 12:00 - 1:50 \\ Instructor: Amy Larson \\ larsona@pdx.edu, Harrison St. Building 101 \\ Office hours: by appointment or drop in
}

Course Objective: This is a reading and discussion class that will focus on the environmental impacts of roads and how they can be mitigated. After taking the class, students should understand the major environmental issues associated with road system construction, maintenance and operation. Guest lecturers will bring real-world perspectives to the class that will help students understand current problems and research needs. Students will also acquire research skills through an individual report and presentation that require a review of primary literature. Scientific reasoning skills and strategies will also be used to complete group projects looking at the ecological effects of the road system.

Tentative Schedule:

\begin{tabular}{|c|c|c|}
\hline Date & Activities & Readings and HW Due \\
\hline 1 April & Introductions, a brief history of roads & \\
\hline 3 April & $\begin{array}{l}\text { Hau Hagedorn, OTREC introduction and } \\
\text { environmental issues }\end{array}$ & $\begin{array}{l}\text { Select topics for } \\
\text { individual papers }\end{array}$ \\
\hline 8 April & $\begin{array}{l}\text { William Fletcher, ODOT - Road effects on water } \\
\text { quality }\end{array}$ & \\
\hline 10 April & $\begin{array}{l}\text { Kerry Rappold, city of Wilsonville - Construction and } \\
\text { use of underpasses }\end{array}$ & \\
\hline 15 April & $\begin{array}{l}\text { Greta Siegel, PSU Library - Reference and library } \\
\text { skills }\end{array}$ & \\
\hline 17 April & $\begin{array}{l}\text { Bill Ryan, ODOT - Bridges and environmental } \\
\text { permits }\end{array}$ & \\
\hline 22 April & $\begin{array}{l}\text { Larson - Habitat fragmentation and population } \\
\text { dynamics }\end{array}$ & $\begin{array}{l}\text { Due Riley et al. } 2006 \\
\text { Proposal/timeline for } \\
\text { project }\end{array}$ \\
\hline 24 April & $\begin{array}{l}\text { Ivy Dunlap, city of Portland Green Streets - Managing } \\
\text { runoff }\end{array}$ & \\
\hline 29 April & $\begin{array}{l}\text { Tom Stahl, Oregon Dept. of Fish and Wildlife - Fish } \\
\text { passages }\end{array}$ & \\
\hline 1 May & $\begin{array}{l}\text { Craig Dewey, National Parks Service - Cultural } \\
\text { considerations }\end{array}$ & Due Mills et al. 2007 \\
\hline 6 May & Student presentations on individual projects & \\
\hline 8 May & $\begin{array}{l}\text { Audry Hatch, ODFW - Linkages: Identifying hotspots } \\
\text { for wildlife corridors }\end{array}$ & \\
\hline
\end{tabular}




\begin{tabular}{|l|l|l|}
\hline 13 May & Keith Mills, ODF - Landslides and forest roads & \\
\hline 15 May & $\begin{array}{l}\text { Will Lackey, ODOT - Weeds and road maintenance } \\
\text { issues }\end{array}$ & Individual papers due \\
\hline 20 May & Linda George, PSU - Air quality & \\
\hline 22 May & $\begin{array}{l}\text { Review and student presentations on individual } \\
\text { projects }\end{array}$ & \\
\hline 27 May & Student presentations on individual projects & \\
\hline 29 May & $\begin{array}{l}\text { Alison Berry, UC-Davis Road Ecology Center - State } \\
\text { of the science }\end{array}$ & $\begin{array}{l}\text { Group reports and grad } \\
\text { papers }\end{array}$ \\
\hline 3 June & Group presentations and grad student discussions & \\
\hline 5 June & Field trip to Boeckman Road Extension & \\
\hline
\end{tabular}

\section{Expectations:}

- Participate daily, ask questions, share your ideas! We have many experts taking time to share their knowledge with you. Please respect their time, think about their ideas and take advantage of their expertise.

- Be prepared for class.

○ Communicate and collaborate with your classmates on group assignments.

- Read assigned papers and come to class prepared for discussions.

- Good grammar, clear structure and scientific reasoning will all be incorporated into your grades.

\section{Academic Conduct:}

- Familiarize yourself with the academic code in the University catalog.

- There are many forms of plagiarism, including:

- Copying word for word without quotation marks and proper citation;

- Closely paraphrasing without proper citation; and

- Be especially careful of information obtained from the Internet. In general, for your written work do not cite work from the Web. Follow the information to its source and cite the primary, peer-reviewed literature.

Text: Road Ecology: Science and Solutions

Grading: Grading: $90-100 \%=\mathrm{A} ; 75-89 \%=\mathrm{B} ; 60-74 \%=\mathrm{C} ; 45-59 \%=\mathrm{D}$

- Participation: A key portion of your grade will be based on the degree to which you are prepared for and participate in class discussions, ask and answer questions, and remain attentive to your peers on a daily basis. Participation will be graded for a total of at least 10 points per day. Attend/prepared for class $=5$ points, contribute once $=7$, multiple contributions $=10$. Particularly insightful comments and questions can earn more points!

- Paper discussions: For each paper we will discuss in class, please read the paper carefully and come to class with at least three questions or comments written up. These will be turned in after each discussion and will count for the "preparedness" portion of your participation score on the relevant days. 
- Projects: Select from one of the group projects. Conduct your project with your group outside of class plus in available class time. You will earn points for participation based on a self and peer evaluation ( 25 points), from a written product from your project (50 points) and from a brief group presentation to the class ( 25 points).

- Individual (or small group) paper and presentation:

○ Undergraduate students: Select a chapter from the text book or a review paper as the starting point for your paper. Use the references therein (or other primary references) to write a review (maximum of five pages) of key research and ideas on the theme. Include in your review an evaluation of at least five primary references (that you have read carefully). Prepare and give a 15- to 20-minute Presentation, including time for questions.

- Graduate students: Select a topic in road ecology and write a paper that synthesizes the current state of the research. Your review should be a maximum of seven pages and include at least 12 primary reference papers. Prepare and give a 20-minute presentation for the class, including time for questions. Select a paper or review for distribution to the class along with discussion questions for your peers to answer. These should be on the same topic as your written paper and presentation. Distribute these to the class one week before your presentation. Lead a 20-minute discussion on the article in class after your presentation. Topic ideas include: sustainable design of roadways; best practices for policy and planning; effectiveness of mitigation; roadways and transport of nonindigenous species; compare and contrast: rural v. urban effects; effectiveness of different materials; and different road planning processes.

- Comprehensive exam: This is based on all materials presented in class, including guest and student presentations. The exam is Thursday, June 12, from 10:15-12:05.

\section{GRADING:}

\begin{tabular}{lcc} 
Component & Undergraduate (\%) & Graduate (\%) \\
\hline Participation & 30 & 30 \\
Projects & 25 & 25 \\
Paper & 15 & 15 \\
Presentation & 15 & 10 \\
Leading discussion \& Quest. & 0 & 5 \\
Comprehensive Exam & 15 & 15
\end{tabular}

\section{Topics and themes for projects:}

Students will add a comparative aspect to the study, "The Effectiveness of Vertebrate Passage and Prevention Structures: A Study of Boeckman Road in Wilsonville." Students will assess multiple roads, including the Boeckman extension, for evidence of passage where structures are in place. As in the main study, wildlife use of structures will be monitored using trail monitors, gypsum powder and observation. The effectiveness of the structure, or the need for passage 
structures, will be assessed through roadkill surveys. Biweekly species-specific roadkill counts and road crossing surveys (gypsum, pellet counts, and observation) will be conducted in April and May in areas with structures, areas along the roads beyond the structures, and, in matched habitats, along roads that lack passage structures. Our partners at ODOT will help us select comparison roads for the Road Ecology class study.

Roadside plantings of a variety of species of plants are conducted in part to reduce runoff and air pollution. Evaluate the effectiveness of several different species of common plants that are found in the same area (freeway adjacent, slope plantings, etc.). Plants can be expected to have varying rates of contaminant uptake rates and contaminant retention (in particular, heavy metals). We are interested in the fate of these heavy metals, whether they are retained in the plant tissues or released back into the environment once the leaves drop or tissues senesce, so sampling should cover several different plants of varying ages. Samples can be prepared and submitted to the OHSU Metals lab for evaluation. This information and recommendations based on this project will be submitted via William Fletcher to ODOT.

Evaluate the effectiveness of swales or retention ponds on water quality. Swales are open channel drainage ways that are used to filter and channel stormwater runoff. ODOT's William Fletcher will work with you to identify swales that are safe to access. Sediment cores can be taken at the surface and at depth to look for accumulation of lead along different roadsides as well as particle size analysis. Similar analyses can be conducted in retention ponds. Students can sample grain size and contaminant levels at the entry and exit points in the ponds.

Select your own project! We would like your project to focus on a road ecology topic with an end product that can be used by researchers, managers or the public.Your independent project should include an impact statement outlining how your work will be used by any of the above. Some examples include an informational video with interviews about the impact of roads on the distribution of species; a guide including the distribution and description of Oregon's roadside species and contact information for reporting sightings; an instructional unit about road ecology for teachers that will address state science standards; or evaluate the effectiveness of different types of fish passages.

\section{Academic Conduct:}

- Familiarize yourself with the academic code in the University catalog.

- There are many forms of plagiarism, including:

○ Copying word for word without quotation marks and proper citation

- Closely paraphrasing without proper citation

$\circ$ Be especially careful of information obtained from the Internet. In general, for your written work do not cite work from the web. Follow the information to its source and cite the primary, peer reviewed literature. 


\section{Rubric:}

$1=$ unconvincing, 2 = many holes, 3 = minor questions, $4=$ completely convincing

\section{Individual Presentation:}

A. Identified and conveyed the importance of the topic.

B. Content was accurate, complete and organized.

C. Identified the broader lessons and conclusions that are applied to this topic.

D. Clearly integrated and explained relevance of primary research articles.

E. Delivered a listener-friendly presentation (within time limits, well rehearsed, confident, eyecontact, projected voice, good pace, etc.).

F. Created a viewer-friendly presentation (font $>18 \mathrm{pt}$, contrasting colors, generally fewer than six words/line and four lines/slide, illustrated, etc.)

\section{Individual Paper:}

A. Identified why road ecology and specific topic are important.

B. Presented a thorough review of the topic (history, current state of knowledge, examples, future directions, etc.).

C. Information appropriately and accurately addresses specific topic.

D. Identified the broader lessons and conclusions that are applied to this topic.

E. Clearly written and organized in own words without typos. Gave credit to all data and ideas of others and included a literature-cited section.

F. Incorporated the minimum number of citations into the text and stayed within the page limit.

\section{Group Project:}
A. Created a useful product
B. Accurate information (no factual mistakes)
C. Thorough and complete
D. Easy to use/read
E. Professional quality product

\section{Within group participation evaluations:}
A. Work completed by the individual was done very well
B. Completed tasks on time
C. Took initiative and responsibility
D. Communicated with the group
E. Worked towards the goals of the project 


\section{APPENDIX C: SEMINAR SERIES}

\section{Environmental Science Seminars}

Spring 2007

ESR 407/507/607

CRN: 61223/61232/61244

PCAT 120

12.00 to 12.50

April 6

Organizational meeting

April 13

Dr. David Jay, Civil and Environmental Engineering, PSU

Tides, River Flow, and Salmon Habitat in the Lower Columbia River

April 20

Toni Pennington, Environmental Science, PSU

Biology and Management of Egeria densa, a Noxious Aquatic Weed

April 27

Dr. Robert Bertini, Oregon Transportation Research and Education Consortium, PSU

OTREC Environmental Priorities and Opportunities

May 4

Kerry Rappold, city of Wilsonville

Boeckman Road Extension - Providing Safe Passage for Wildlife and Maintaining Habitat Connectivity

May 11

Keith Mills, Oregon Department of Forestry

Evaluating Risks from Low-volume Roads to Water and Aquatic Resources

May 18

Bryan Black, HDR Inc.

Membrane Treatment in the City of St. Helens Water Treatment Plant

May 25 TBA

June 1

Ray Willard, Washington Department of Transportation

Integrated Roadside Vegetation Management 


\section{APPENDIX D: FIELD TRIP PHOTOS}

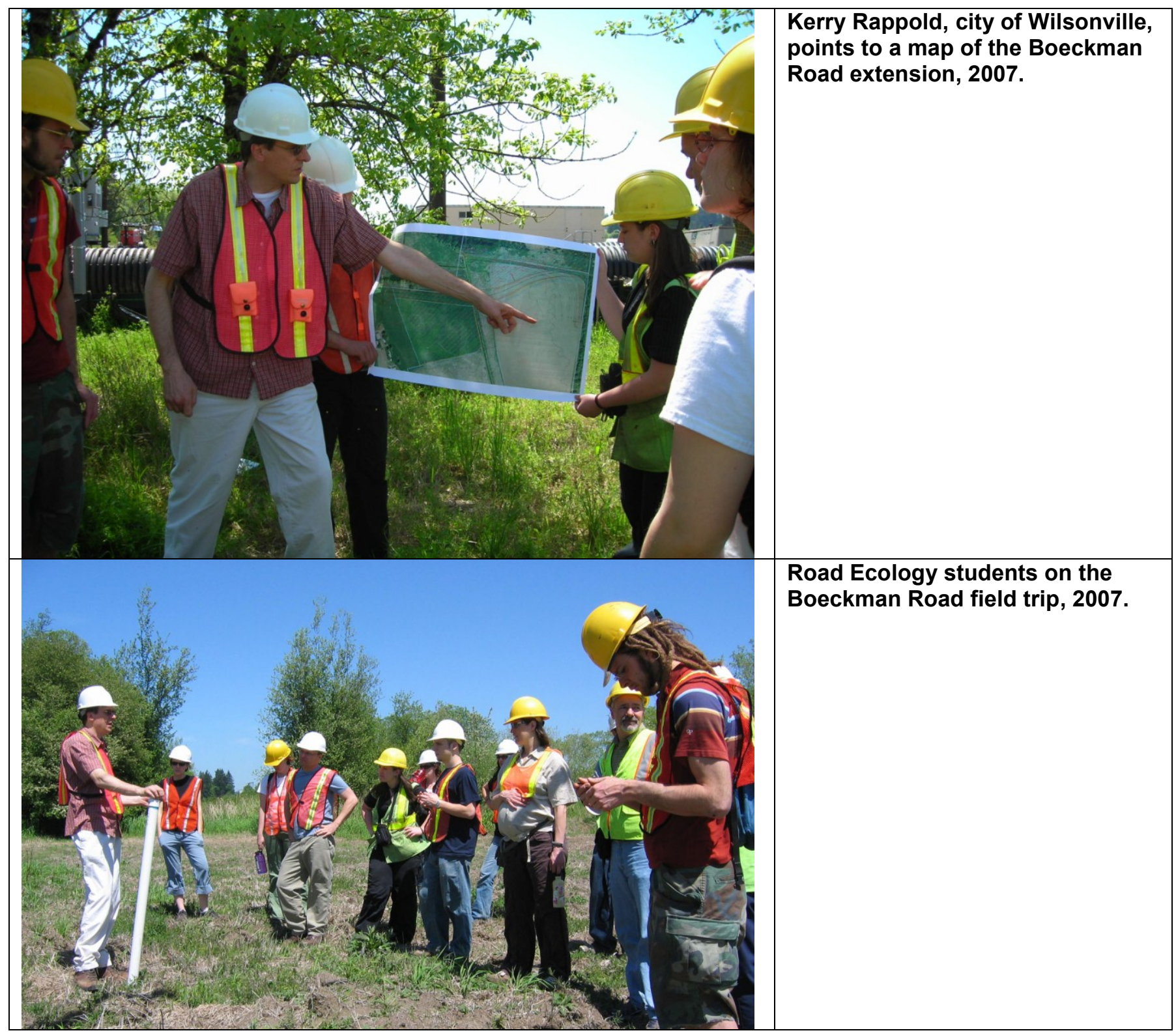




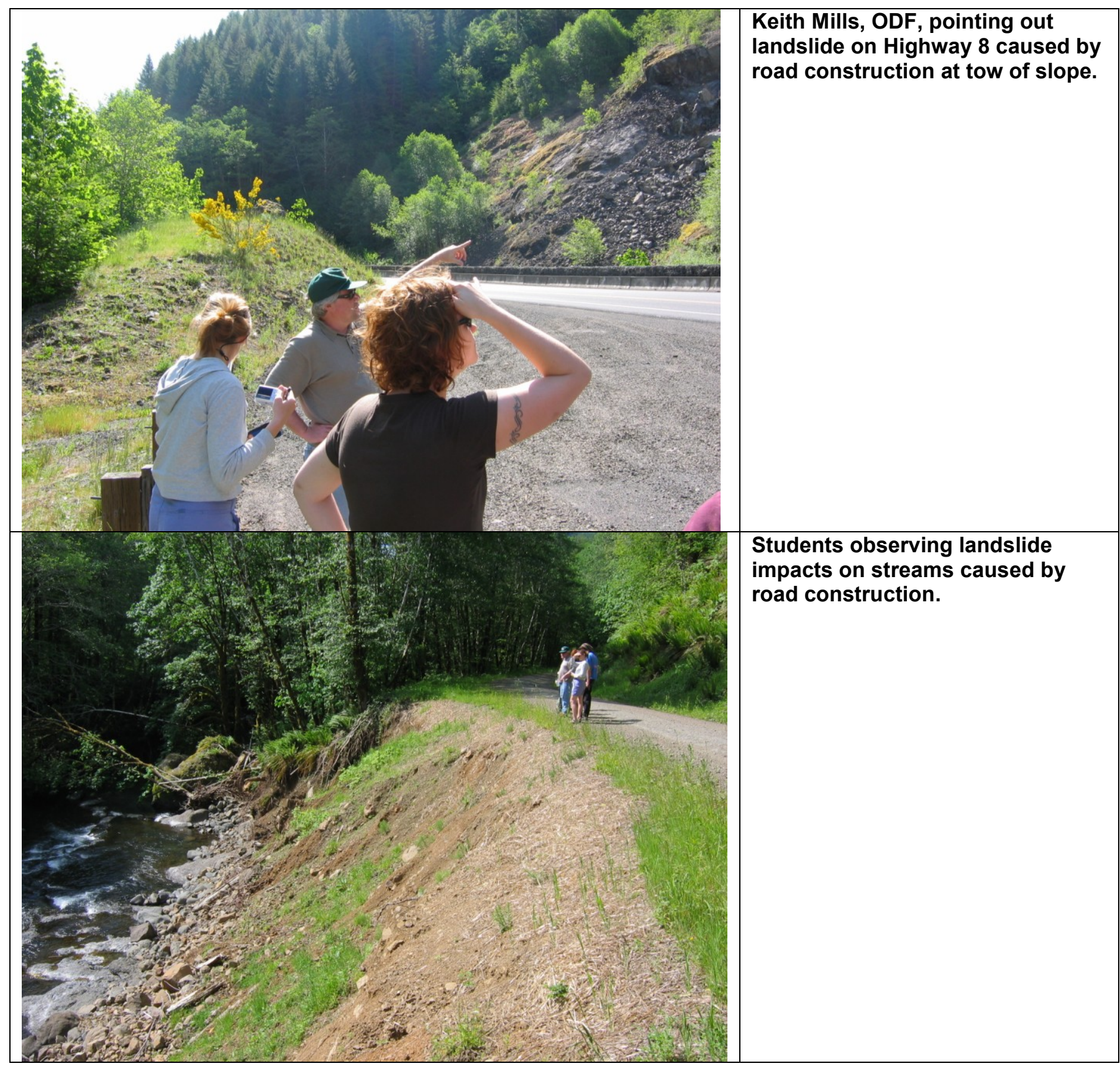




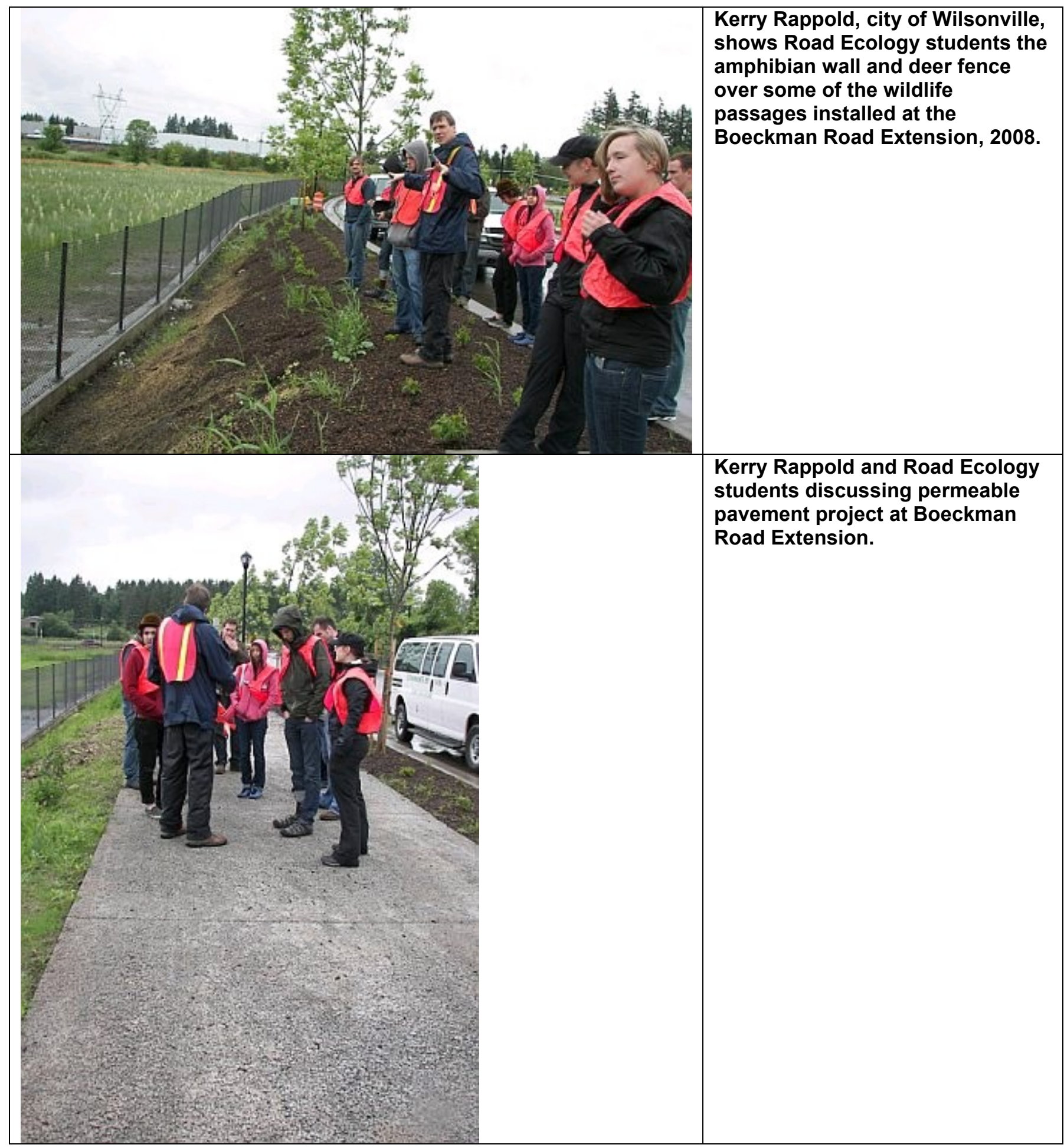




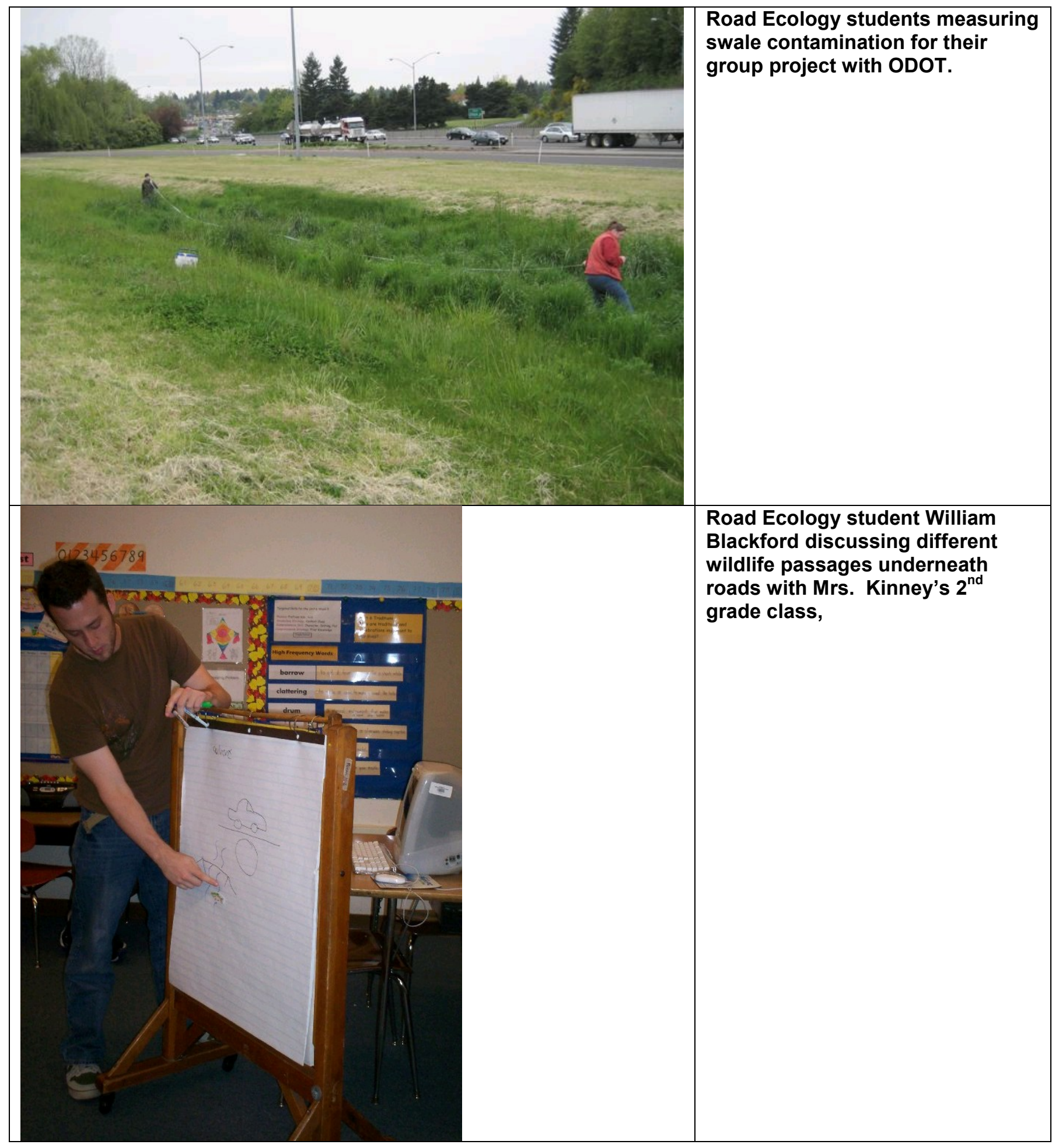




\section{APPENDIX E: EVALUATION FORM FOR STUDENT PRESENTATIONS}

\section{Group Name: \\ Your Name:}

\section{Content of the presentation:}

What are the main issues associated with this group's topic?

With respect to this topic, what are the most significant challenges for professionals (engineers, biologists, planners, etc.)?

Based on what you learned from this presentation, what types of solutions have been offered to overcome these challenges?

What surprised you, or what did you learn from this presentation that you did not learn from other speakers visiting the class?

Did the speakers adequately cover important aspects of this problem and provide sufficient time for discussion?

Circle the best choice; $1=$ poor, $5=$ excellent

$\begin{array}{llllll}1 & 2 & 3 & 4 & 5 & \text { Relevance of the advance reading provided by the group }\end{array}$

$\begin{array}{llllll}1 & 2 & 3 & 4 & 5 & \text { The group appears to understand the topic }\end{array}$

$\begin{array}{llllll}1 & 2 & 3 & 4 & 5 & \text { Level of preparedness by the group }\end{array}$

$\begin{array}{llllll}1 & 2 & 3 & 4 & 5 & \text { Equal participation by all group members }\end{array}$ 


\section{Mechanics of the presentation}

Was the group engaged with the audience and did group members handle post-presentation clearly and concisely?

Did you find the presentation effective? For example, were slides superfluous, confusing, clear or helpful?

Circle the best choice; 1 = poor, 5 = excellent

$\begin{array}{llllll}1 & 2 & 3 & 4 & 5 & \text { Clarity of the speakers }\end{array}$

$\begin{array}{llllll}1 & 2 & 3 & 4 & 5 & \text { Eye contact }\end{array}$

$\begin{array}{llllll}1 & 2 & 3 & 4 & 5 & \text { Professionalism }\end{array}$

$\begin{array}{llllll}1 & 2 & 3 & 4 & 5 & \text { Pace of the presentation }\end{array}$

$\begin{array}{llllll}1 & 2 & 3 & 4 & 5 & \text { Your ability to follow the group's train of thought }\end{array}$

\section{Recommendations for the group:}

If applicable, can you suggest an alternative structure to the presentation?

What were the strengths and weaknesses of the presentation? 


\section{APPENDIX F: STUDENT COMMENTS}

Student comments on Road Ecology Spring 2008:

\section{Q: What was the most valuable thing you learned in this course?}

- To take an interdisciplinary approach when looking at a subject as complex as Road Ecology. I think it was valuable to learn about our impacts on the environment and the types of problems that are out there and how to solve those problems. I am interested in getting involved with those programs, so it was nice to see what agencies are out there.

- Learning about roadside plants is fascinating. Before I just thought, "Why don't they just have all native plants along roadsides?" Now I understand the reasons for placement and spacing and certain species are better and easier to maintain, etc. There is so much room for improvement!

- That we need to look at the environmental issues at the beginning - not at the end!

- How much our roads and vehicles REALLY effect not only our wildlife but our quality of life as well.

- The most valuable thing I learned was that roads fracture animal populations. I never even thought about it before.

- How great of an affect our roads have on the environment and wildlife.

- When thinking about road ecology, I really only thought of the environmental issues. I learned a lot about how roads affect wildlife.

- I learned how concern about roads affects the U.S. because in Thailand there are less concern about these topics. Also I never studied any course about road ecology before.

- 1 - the nature of compound effects of road networks. 2-RTF is the man.

- The interrelationship of all the variables affected by roads makes research and evaluation difficult. Understanding impacts requires accounting for a lot of variation, and there is rarely a one-size-fits-all solution to the problem of roads.

- I think Linda George's insight on biodiesel-driven engines in comparison with standard diesel engines was the biggest shocker, and I will look more closely into alternatives before I endorse them.

- The importance of education about this area. I had never heard of it before!

- Fish passages are very specific and one mishap could ruin them.

\section{Q: What was your favorite aspect of this course?}

- Guest speakers - the variety of talks helped to give me a broad perspective and new subject matter kept the class engaging and interesting.

- When I drive, I notice so much more about my surroundings, and I know more about the interactions and reasons behind planning of roadsides.

- My favorite aspect was fish passage! How to facilitate it and reduce our impact on anadromous fish.

- All of it is very real-world applicable. 
- My favorite was having Amy for an instructor, but a close second was hearing all the real-world speakers.

- The wildlife being affected portion interested me most.

- I really enjoyed our group projects. It was great to collaborate and see what skills members could contribute.

- To know many knowledge from many expert from many fields.

- I really enjoyed actually seeing the Boeckman extension. The more field activity the better.

- Hearing the presenters bring in their real-world experiences that illustrate the concepts we were studying.

- This was the best group project I have ever completed, as well as the most useful. I am pleased to be sending our findings onto ODOT as they have never been able to carry out this type of experiment before.

- The group projects.

- Being out on the road with Leslie counting road kill. Also all of the experts who came in to talk.

\section{Q: What part of this course could use improvement?}

- More time to discuss the lectures and talks could have helped me to focus on important concepts, or at least what the main / key points were. More lectures to tie information together.

- 20 minutes (at least) after each presentation where you explain parts of the lecture that needed more explaining or went into more detail, or tied it into our reading. It would help it all sink in and have more meaning.

- If we could talk about the speakers as a class after they left, like when we had our readings... get in a big circle and just chat.

- More lectures by you! And really, did we need the book for class?

- I find this class was interesting and well taught. However I would have liked to have people bring snacks.

- Some of the speakers could be correlated more so week to week they would be talking about similar things.

- I think more lectures by you could have been helpful. Maybe a weekly quiz so that information would stick better.

- If there is a handout for each class, this will help to take note and understand content from guest speakers.

- More structured lectures before the guest speakers to lay a framework. Also more required reading from the book.

- Talk about the text book more. It's a really good book!

- The workload of 2 presentations, 2 papers and 1 final and assorted reading-driven assignments took away from the subject. Also just put the material on the Idrive. Things on blackboard were out of order and some material was missing. I want to learn the material not learn how to fish out what I need from a program.

- Maybe another field trip, getting out there and seeing it helps.

- I think the online function (blackboard) could have been used better. 
P.O. Box 751

Portland, OR 97207

www.otrec.us

OTREC is dedicated to stimulating and conducting collaborative multi-disciplinary research on multi-modal surface transportation issues, educating a diverse array of current practitioners and future leaders in the transportation field, and encouraging implementation of relevant research results. 